\title{
Cancer patients' desire for information: a study in a teaching hospital in Saudi Arabia
}

A.M. Al-Amri ${ }^{1}$

$$
\begin{aligned}
& \text { رغبة مرضى السرطان في المعرفة: دراسة في مستشفى تعليمي في المملكة العربية السعودية } \\
& \text { على محمد صالح العمريه مريى }
\end{aligned}
$$

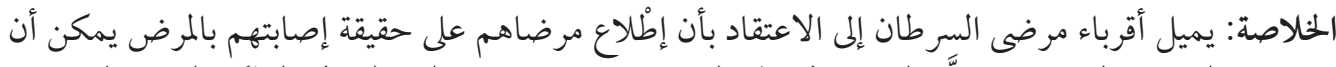

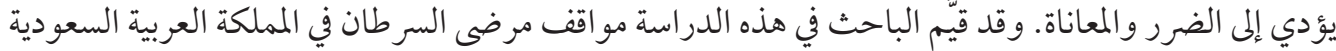

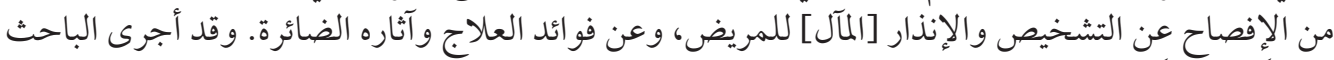

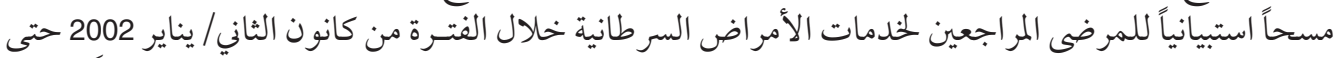

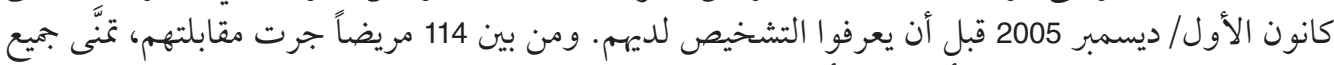

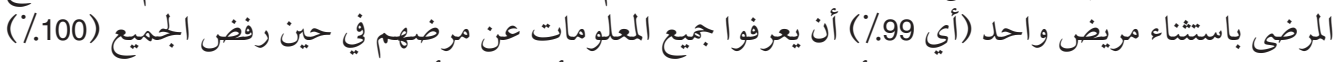

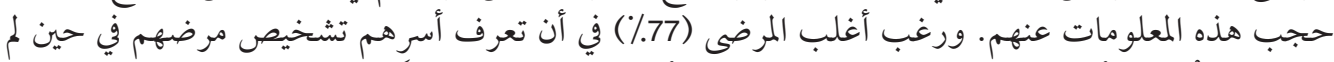

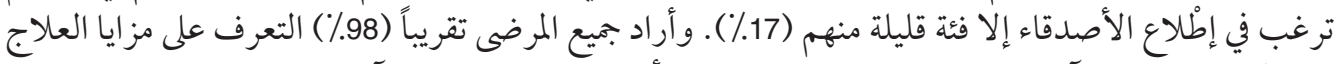

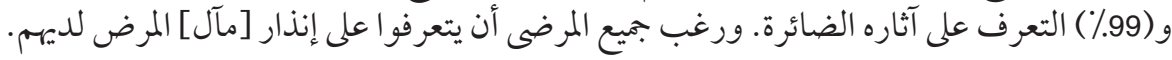

ABSTRACT Relatives of cancer patients in Saudi Arabia tend to believe that telling the truth to the patient could lead to harm and suffering. This study assessed the attitudes of Saudi Arabian cancer patients towards disclosure of cancer diagnosis and prognosis, and benefits and adverse effects of therapy. A questionnaire survey was administered to patients attending the oncology service between January 2002 and December 2005 before they knew their diagnosis. Of 114 patients interviewed, all except $1(99 \%)$ wished to know all the information about their disease and $100 \%$ rejected withholding information. Most of the patients $(77 \%)$ wanted their family to know the diagnosis but few $(17 \%)$ wanted their friends to be informed. Almost all patients wanted to know the benefits and adverse effects of therapy (98\% and $99 \%$ respectively). All patients wanted to know about the prognosis of their disease.

Volonté de savoir chez les patients atteints de cancer : étude dans un hôpital universitaire d'Arabie saoudite

RÉSUMÉ Les proches des patients cancéreux en Arabie saoudite ont tendance à penser que le fait de dire la vérité au patient peut lui faire du mal et le faire souffrir. Cette étude a évalué l'attitude des patients cancéreux saoudiens vis-à-vis de l'annonce du diagnostic de cancer et de son pronostic, ainsi que de l'intérêt et des effets indésirables du traitement. Une enquête par questionnaire a été réalisée auprès des patients fréquentant le service d'oncologie entre janvier 2002 et décembre 2005 avant qu'ils n'apprennent le diagnostic de leur maladie. Sur 114 patients interrogés, tous sauf 1 (99\%) souhaitaient tout savoir sur leur maladie et $100 \%$ refusaient qu'on leur cache des informations. La plupart d'entre eux $(77 \%)$ souhaitaient que leur famille soit informée du diagnostic mais peu (17\%) que leurs amis en soient informés. Presque tous les patients souhaitaient connaître l'intérêt et les effets indésirables du traitement (respectivement $98 \%$ et $99 \%$ ). Tous voulaient connaître le pronostic de leur maladie.

${ }^{1}$ Department of Internal Medicine and Medical Oncology, King Fahd Hospital of the University, King Faisal University, Al-Khobar, Saudi Arabia (Correspondence to A.M.Al-Amri: aliamri49@hotmail.com).

Received: 01/06/06; accepted: 27/08/06

المجلة الصحية لشرق المتوسط، منظمة الصحة العالمية، المجلد الخامس عشر، العلد (، 9.9. 


\section{Introduction}

Cancer is a major life-threatening disease that can evoke deep-rooted fear of death and sense of loss of hope. Even the word, cancer, has powerful connotations of anxiety, pain and suffering.

Studies from many countries show that, despite fear of cancer, a majority of both healthy adults and cancer patients prefer to know their diagnosis, prognosis, options for treatment and the likely success of therapy [1-5]. However, in the past there was a convention among physicians of not giving full information to cancer patients. Novack et al. reported that in a questionnaire in 1961, $90 \%$ of American physicians preferred not to tell a cancer patient his/her diagnosis. By 1977 , this had reversed, with $97 \%$ preferring to tell a cancer patient the diagnosis [4]. Nowadays, in many developed countries, the attitudes of physicians towards informing cancer patients about their diagnosis have changed to truth-telling and disclosure of all important facts related to the disease [4-9].

In Saudi Arabia, despite religious and social taboos about lying and the risk of loss of trust, the relatives of cancer patients often defend the right of the patient not to know about his/her diagnosis and prognosis and insist on treating the patient without telling him/her or requesting signed consent for treatment. This study was conducted to explore the opinion of Saudi Arabian cancer patients about how much information they would like to know about their diagnosis, prognosis, treatment benefits and the adverse effect of therapy.

\section{Methods}

All of the study patients were Saudi Arabian nationals who were suspected of malignant disease and referred for diagnosis to King Fahd Hospital of the University at
Al-Khobar from January 2002 to December 2005. Both male and female patients were included in this study and all patients were over 18 years old.

The patients were given a structured interview to gauge their opinion about how much information they wished to know about their diagnosis, prognosis, treatment benefits and side-effects if their disease proved to be cancer. The interviews were carried out after the diagnosis of cancer had been made at the hospital but before the patients knew their diagnosis. After taking verbal consent for participation, the author interviewed each patient. The attitudes of relatives of cancer patients in our community as well as the purpose of the study were explained to the patients. Each question was explained and the patients were asked to respond according to their own point of view after the questions were translated into their local language if needed. Patients were allowed to answer the questions without help or guidance.

The questionnaire had 9 items, modified from those used by Meredith et al. [10], Fallowfield et al. [11] and Jawaid et al. [12]:

- Do you want to know all the information about your illness?

- Do you want to know only partial information?

- Should we withhold all the information?

- Should we tell your family?

- Should we tell your friends?

- Should we treat you without telling you about the effect of the treatment?

- Should we treat you without telling you about your disease if it proves to be cancer?

- Do you want to know all side-effect of the treatment?

- Do you want to know about the prognosis of the disease? 


\section{Results}

A total of 114 consecutive Saudi cancer patients (67 females and 47 males) were interviewed before the result of histopathology and confirmation of their malignant disease. All of them were Muslims from different regions of Saudi Arabia. The majority $(61 \%)$ were from the Eastern Province and just over half were illiterate (52\%) (Table 1). More than half of the patients had breast carcinoma or lymphoma.

Table 2 lists the answers to the questionnaire. In response to the first 3 questions, only 1 patient wanted to know partial information and $113(99 \%)$ of the patients wished to know the information in detail. None of the patients wanted information to be hidden from them. In response to questions about informing friends and family, 88 (77\%) patients wanted their family to know about their diagnosis but only 19 (17\%) wanted their friends to know.

All of the patients rejected the idea of treatment without knowing their diagnosis and had a strong desire to know about the treatment 113 (99\%). Only 1 patient did not want to know the adverse effects of treatment. All patients wanted to know about the prognosis of their malignant disease.

There were no major differences in the patients' attitude toward disclosure of information about their disease and its treatment with respect to educational level and sex of the patients (Table 3 ).

\section{Discussion}

Surveys of cancer patients in developed countries indicate that the majority of patients prefer to know their diagnosis, options of treatment, adverse effects of therapy and prognosis of their malignant disease $[1,5,6,10]$. A survey of 1251 Ameri- cans showed that $96 \%$ of patients wished to be told if they were suffering from cancer and $85 \%$ wished to know how long they were going to survive [13]. European patients had a similar attitude. Meredith et al. studied 250 patients attending an oncology centre in Scotland and showed that $96 \%$ wanted to know if their illness was cancer [10]. In the present study, almost all of the patients wanted to know their diagnosis; $100 \%$ would not like to be treated without knowing the diagnosis and $99 \%$ wanted to

\begin{tabular}{lrr}
\hline $\begin{array}{l}\text { Table 1 Demographic characteristics of the } \\
\text { study patients }(\boldsymbol{n}=\mathbf{1 1 4})\end{array}$ & \multicolumn{1}{c}{ No. } \\
\hline Variable & & \\
\hline Age (years) & 114 & 100 \\
$\quad$ 18-85 & & \\
Sex & 47 & 41 \\
$\quad$ Male & 67 & 59 \\
Female & & \\
Province & 70 & 61 \\
Eastern & 9 & 8 \\
Central & 5 & 4 \\
Western & 21 \\
Southern & 24 & 5 \\
$\quad$ North & 6 & \\
Religion & & 100 \\
$\quad$ Muslim & 114 & \\
Level of education & & \\
Illiterate & 59 \\
Read and write & 4 & 4 \\
Primary school & 12 & 10 \\
Intermediate school & 12 & 10 \\
Secondary school & 11 & 10 \\
University & 16 & 14 \\
Type of cancer & & \\
Lymphoma & 35 & 31 \\
Breast cancer & 31 & 27 \\
Lung cancer & 10 & 9 \\
Other & 38 & 33 \\
\hline
\end{tabular}


Table 2 Responses of Saudi Arabian cancer patients $(n=114)$ to questionnaire about information giving

\begin{tabular}{lrrrr}
\hline Question & \multicolumn{2}{c}{ Yes } & \multicolumn{2}{c}{ No } \\
& No. & $\%$ & No. & $\%$ \\
\hline Do you want to know all information about your illness? & 113 & 99 & 1 & 1 \\
Do you want to know only partial information? & 1 & 1 & 113 & 99 \\
Should we withhold all information? & 0 & 0 & 114 & 100 \\
Should we tell your family? & 88 & 77 & 26 & 23 \\
Should we tell a friend? & 19 & 17 & 95 & 83 \\
Should we treat without telling you the effects of & & & & \\
$\quad$ treatment? & 2 & 2 & 112 & 98 \\
Should we treat without telling you about your disease? & 0 & 0 & 114 & 100 \\
Do you want to know about the treatment side-effects? & 113 & 99 & 1 & 1 \\
Do you want to know about the prognosis? & 114 & 100 & 0 & 0 \\
\hline
\end{tabular}

know the benefits and adverse effects of therapy.

Cultural and social factors in Saudi Arabia play a major role in giving bad news and truth-telling about cancer diagnosis, treatment and prognosis. From the author's per- sonal experience, relatives of Saudi patients believe that telling the truth to the patient could lead to harm and suffering and some believe that patients are not sufficiently well educated to understand medical terminology. Almost all of the family caregivers

Table 3 Responses of Saudi Arabian cancer patients to questionnaire about information giving by level of literacy and sex

\begin{tabular}{|c|c|c|c|c|c|c|c|c|}
\hline \multirow[t]{2}{*}{ Question } & \multicolumn{2}{|c|}{$\begin{array}{c}\text { Literate } \\
(n=55) \\
\text { Yes }\end{array}$} & \multicolumn{2}{|c|}{$\begin{array}{c}\text { Illiterate } \\
(n=59) \\
\text { Yes }\end{array}$} & \multicolumn{2}{|c|}{$\begin{array}{c}\text { Females } \\
(n=67) \\
\text { Yes }\end{array}$} & \multicolumn{2}{|c|}{$\begin{array}{c}\text { Males } \\
(n=47) \\
\text { Yes }\end{array}$} \\
\hline & No. & $\%$ & No. & $\%$ & No. & $\%$ & No. & $\%$ \\
\hline $\begin{array}{l}\text { Do you want to know all information } \\
\text { about your illness? }\end{array}$ & 51 & 93 & 59 & 100 & 66 & 99 & 47 & 100 \\
\hline $\begin{array}{l}\text { Do you want to know only partial } \\
\text { information? }\end{array}$ & 1 & 2 & 0 & 0 & 1 & 2 & 47 & 100 \\
\hline Should we withhold all information? & 0 & 0 & 0 & 0 & 0 & 0 & 47 & 100 \\
\hline Should we tell your family? & 35 & 64 & 53 & 90 & 56 & 84 & 35 & 75 \\
\hline Should we tell a friend? & 9 & 16 & 10 & 17 & 10 & 15 & 9 & 19 \\
\hline $\begin{array}{c}\text { Should we treat you without telling } \\
\text { you the effects of treatment? }\end{array}$ & 2 & 4 & 0 & 0 & 1 & 2 & 1 & 2 \\
\hline $\begin{array}{l}\text { Should we treat you without telling } \\
\text { you about your disease? }\end{array}$ & 0 & 0 & 0 & 0 & 0 & 0 & 0 & 0 \\
\hline $\begin{array}{l}\text { Do you want to know about the } \\
\text { treatment side-effects? }\end{array}$ & 1 & 2 & 59 & 100 & 67 & 100 & 46 & 98 \\
\hline $\begin{array}{l}\text { Do you want to know about the } \\
\text { prognosis? }\end{array}$ & 52 & 95 & 59 & 100 & 67 & 100 & 47 & 100 \\
\hline
\end{tabular}


request a written medical report with full medical information so that they can seek a second opinion or treatment abroad.

The results of this study indicate that the Saudi cancer patients who were interviewed at our hospital prefer to know the truth about their illness, the prognosis and the treatment available. All the patients were of Saudi Arabian nationality and from different regions of the country. The study was designed to explore whether cancer patients in Saudi Arabia might have different attitudes compared with patients in developed countries, where there is a more individualistic philosophy and where most cancer patients want detailed information about their cancer [10,14-19]. However, we found that Saudi cancer patients were not different from those in other parts of the world.

In Saudi Arabia, there are 5 sociocultural factors that may play a role in decisions about how much information to give cancer patients: (1) the family are key participants in medical-related decision-making; (2) patients are not financially autonomous; (3) medical oncologists are trained in the European and American medical traditions; (4) lying to patients is not a valid option for a physician; and (5) there is a lack of institutional policies regarding the disclosure of diagnoses. These factors may lead to doctor-patient conflict when discussing cancer diagnosis, treatment advantages and side-effects and prognosis, especially in cultures where there is not full acceptance of the principles of informed consent and patient autonomy [20-22].

The present study had several limitations. First, the sample size was small. Secondly, since the study was done at a single institution and by a single researcher, there could be a bias towards a positive outcome. Thirdly, the participants were predominantly from the Eastern Province and may not be representative of all Saudi cancer patients; however, the Eastern Province has a diverse population and there were participants from the other regions of Saudi Arabia. A multicentre study with a larger sample size would allow for more definite conclusions about the attitude of cancer patients in the country as a whole.

In summary, contrary to what many people in Saudi Arabia believe, these findings demonstrate that cancer patients do want to know the truth about the diagnosis, benefits and adverse effects of therapy and prognosis of their malignant disease.

\section{Acknowledgements}

I would like to extend my sincere gratitude to Professors Hassan Bella and Sadat Ali for their valuable contribution in revising the manuscript and for their suggestions and comments in preparing this paper.

\section{References}

1. Cassileth BR et al. Information and participation preferences among cancer patients. Annals of internal medicine, 1980, 92:832-6.

2. Noone I et al. Telling the truth about cancer: views of elderly patients and their relatives. Irish medical journal, 2000, 93:104-5.
3. Pimentel FL et al. Quantity and quality of information desired by Portuguese cancer patients. Supportive cancer patients, 1999, 7:407-12.

4. Novack DH et al. Changes in physicians' attitudes toward telling the cancer patients. Journal of the American Medical Association, 1979, 241:897-900. 
5. Jenkins V, Fallowfield L, Saul J. Information needs for cancer patients: result from a large study in UK cancer centres. British journal of cancer, 2001, 84:48-51.

6. Sutherland $\mathrm{HJ}$ et al. Cancer patients: their desire for information and participation in treatment decisions. Journal of the Royal Society of Medicine, 1989, 82:260-3.

7. Tanida N. Japanese attitude toward truth disclosure in cancer. Scandinavian journal of sociology and medicine, 1994, $1: 50-7$.

8. Hosaka T et al. Disclosure of true diagnosis in Japanese cancer patients. General hospital psychiatry, 1999, 21:209-13.

9. Horikawa $\mathrm{N}$ et al. Changes in disclosure of information to cancer patients in general hospital in Japan. General hospital psychiatry, 2000, 22:37-42.

10. Meredith $\mathrm{C}$ et al. Information needs of cancer patients in west Scotland: cross sectional survey of patients' views. British medical journal, 1996, 313:724-6.

11. Fallowfield L, Ford S, Lewis S. Information preferences of patients with cancer. Lancet, 1994, 344:1576.

12. Jawaid M, Afsar S, Jawaid SA. Questionnaire based survey of general population to assess their views about disclosure of cancer diagnosis and review of literature. Pakistan journal of medical sciences, 2003, 19:81-8.

13. President's Commission for the Study of Ethical Problems in Medicine and Biomedical and Behavioral Research. Making health care decisions: a report on the ethical and legal implications of informed consent in the patient-practitioner rela- tionship. Washington DC, Government Printing Office, 1982:119.

14. Sardell AN, Trierweiler SJ. Disclosing the cancer diagnosis. Procedures that influence patient hopefulness. Cancer, 1993, 72:3355-65.

15. Yun YH et al. The attitudes of cancer patients and their families toward the disclosure of terminal illness. Journal of clinical oncology, 2004, 22:307-14.

16. Hagerty $R G$ et al. Cancer patient preferences for communication of prognosis in the metastatic setting. Journal of clinical oncology, 2004, 22:1721-30.

17. Mystakidou $\mathrm{K}$ et al. Disclosure of diagnostic information to cancer patients in Greece. Palliative medicine, 1996, 10:195-200.

18. Kaplowitz SA, Campo S, Chui WT. Cancer patients desire for communication of prognosis information. Health communication, 2001, 14:221-41.

19. Lamont EB, Christakis NA. Prognostic disclosure to patients with cancer near the end of life. Annals of internal medicine, 2001, 134:1096-105.

20. Goldberg RJ. Disclosure of information to adult cancer patients: issues and update. Journal of clinical oncology, 1984, 2:948-55.

21. Annas G. Informed consent, cancer, and truth in prognosis. New England journal of medicine, 1994, 330:223-5.

22. Smith TJ, Swisher K. Telling the truth about terminal cancer. Journal of the American Medical Association, 1998, 279:1746-8. 